\title{
Penggunaan Literatur dalam Penulisan Karya Ilmiah Mahasiswa Agroteknologi Instiper Yogyakarta (Studi Bibliometrika pada Jurnal Agromast Tahun 2018-2019)
}

\author{
Laylatul Munawaroh ${ }^{1}$, Marwiyah ${ }^{2}$ \\ ${ }^{1}$ Program Pascasarjana Konsentrasi Ilmu Perpustakaan dan Informasi UIN \\ Sunan Kalijaga, ${ }^{2}$ Program Studi Ilmu Perpustakaan dan Informasi UIN \\ Sunan Kalijaga \\ laylatulmunawaroh1@gmail.com
}

\begin{abstract}
This study aims to determine the dominance of reference sources, types of references, the most cited authors, the availability of collections in the Stiper Institute of Agriculture (Instiper) library and the reference year used by students in preparing scientific papers. This study uses a quantitative descriptive approach and bibliometric studies with citation analysis and literary life half-life. The object of analysis in this research is 166 scientific articles published in the journal Agromast published in 2018-2019. The results showed that: 1) types of reference sources or information materials used as references for students in writing scientific papers were dominated by types of references in the form of books (74.90\%) and scientific articles (16.10\%). 2) The half-life age of the literature cited in the journal Argomast as a whole from 2018 to 2019 is 8 years. $75.59 \%$ of the literature that is considered up-to-date or obsolete, while the literature that is considered current is $28.15 \%$. Thus, the literature used as a reference in the Agromast journal 2018-2019 tends to use less up-to-date literature.
\end{abstract}

Keywords: Bibliometric; Citation Analysis; Half Life Literature

\begin{abstract}
Abstrak
Penelitian ini bertujuan untuk mengetahui dominasi sumber-sumber referensi, jenis referensi, pengarang yang paling banyak disitir, ketersediaan koleksinya di perpustakaan Institut Pertanian Stiper (Instiper) serta tahun referensi yang digunakan mahasiswa dalam penyusunan karya ilmiah. Penelitian ini mengunakan metode pendekatan deskriptif kuantitatif dan kajian bibliometrika dengan analisis sitiran serta paro hidup litaratur. Objek analisis dalam penelitian ini adalah 166 artikel ilmiah yang dimuat dalam jurnal Agromast yang terbit pada tahun 2018-2019. Hasil penelitian menunjukkan bahwa: 1) jenis sumber rujukan atau bahan informasi yang dijadikan referensi mahasiswa dalam menulis karya ilmiah didominasi oleh
\end{abstract}


jenis rujukan berupa buku-buku (74.90\%) dan artikel ilmiah (16.10\%). 2) Usia paro hidup literatur yang dikutip pada jurnal Argomast secara keseluruhan dari tahun 2018 sampai 2019 adalah 8 tahun. Literatur yang dianggap tidak mutakhir atau usang sebanyak $75.59 \%$, sedangkan literatur yang dianggap mutakhir sebanyak $28.15 \%$. Dengan demikian, literatur yang digunakan sebagai referensi pada jurnal Agromast tahun 2018-2019 cenderung menggunakan litertur yang tidak mutkahir.

Kata Kunci: Bibliometrika; Analisis Sitiran; Paro Hidup

\section{A. PENDAHULUAN}

Penyelenggaraan penelitian dan pengembangan ilmu pengetahuan merupakan bagian dari kegiatan dalam mewujudkan Tri Dharma Perguruan Tinggi, penelitian-penelitian yang dilakukan dapat menghasilkan perkembangan teknologi, produk, sosial, budaya dsb. sebagai keluaran (output) implementasi dari hasil penelitian. Umumnya, mahasiswa perguruan tinggi telah terbiasa dengan membuat penelitian, laporan, dan tugas akhir dalam bentuk karya ilmiah sebagai persyaratan kelulusan. Salah satu bentuk dari karya ilmiah adalah artikel ilmiah yang biasanya dimuat dalam jurnal yang terdiri dari beberapa artikel ilmah. Jurnal ilmiah adalah terbitan yang berisi tulisan ilmiah yang diterbitkan secara berkala, jurnal ilmiah juga sebagai media penghubung antara penulis dan pembaca. Jurnal ilmiah biasanya diterbitkan secara komersial maupun non komersial oleh Asosiasi Keilmuan, Lembaga Riset, dan Perguruan Tinggi (Muchlisin, 2018).

Keberadaan lembaga perpustakaan dalam lingkungan perguruan tinggi, menjadi unsur pendukung dalam menyediakan sumber informasi bagi penyusunan karya tulis ilmiah. Dalam proses penulisan karya ilmiah sangat penting menggunakan literatur atau pustaka sebagai dasar teori dari studi yang sedang dikembangakan. Penggunaan literatur tersebut dapat memperkaya bahasan yang sedang dikaji (Fatchiyah, 2016). Sumber-sumber informasi yang dapat dijadikan bahan referensi dalam pembuatan karya ilmiah bagi mahasiswa sebagian besar dapat ditemukan di perpustakaan, hal tersebut merupakan bagian dari peran penting kehadiran perpustakaan di lingkungan perguruan tinggi dalam menunjang kegiatan akademik. Untuk dapat mewujudkan peran perpustakaan tersebut, penting bagi perpustakaan melakukan evaluasi terhadap sumber-sumber informasi dan bahan perpustakaan yang relevan dengan kebutuhan pemustaka.

Institut Pertanian Stiper (Instiper) Yogyakarta adalah perguruan tinggi yang berkompetensi pada bidang perkebunan dan pertanian yang berlokasi di Daerah Istimewa Yogyakarta. Instiper memiliki perpustakaan yang terdiri dari 4 lantai dengan seluas $2500 \mathrm{~m}^{2}$, perpustakaan tersebut 
menyimpan banyak sumber informasi dan literatur untuk menunjang kegiatan penelitian dan akademik di lingkungan Instiper. Perpustakaan memiliki koleksi yang sebagian besar memprioritaskan koleksi di bidang ilmu pertanian dan perkebunan sesuai dengan konsentrasi keilmuan institusi yang menaunginya. Walaupun demikian, perpustakaan Instiper juga melakukan pengadaan dan menyajikan koleksi-koleksi bidang ilmu umum lainnya. Berdasarkan observasi yang dilakukan peneliti di perpustakaan Instiper, koleksi bidang ilmu pertanian dan perkebunan yang dimiliki perpustakaan Instiper sangat beragam jenisnya, dari mulai buku, jurnal, majalah, diktat, dan karya ilmiah dari mulai tahun terbitan lama hingga yang terbaru. Perpustakaan Instiper memiliki beragam koleksi buku dan diktat dengan tahun terbit yang lama, dalam wawancara peneliti dengan Ibu Helmi Afroda selaku kepala perpustakaan Instiper menyatakan penyebabnya adalah dalam menghadirkan koleksi-koleksi bidang pertanian dan perkebunan cukup sulit dilakukan oleh pihak perpustakaan, dikarenakan sulitnya mendapatkan koleksi tersebut di pasaran (Afroda, wawancara, 04 Maret 2020). Sehingga pengadaan koleksi baru dalam skala yang besar cukup sulit dilakukan. Oleh karena itu, koleksi yang masih berdaya guna bagi pemustaka tidak bisa disingkirkan dari jajaran rak meskipun koleksi tersebut termasuk koleksi dengan tahun terbit yang telah lama.

Dalam kondisi tersebut perpustakaan perlu melakukan evaluasi koleksi untuk mengetahui kebutuhan sumber informasi pemustaka, khususnya mahasiswa Instiper dalam menggunakan rujukan pada penulisan karya ilmiah dan tugas akhir mahasiswa. Untuk dapat mengetahui koleksi apa yang dibutuhkan oleh pemustaka dalam suatu perpustakaan perguruan tinggi, evaluasi koleksi penting dilakukan agar keseimbangan antara ketersedian informasi dengan kebutuhan pemustaka dapat terpenuhi. Salah satu metode dalam melakukan evaluasi yang dapat dilakukan pustakawan adalah melalui kajian bibliometrika yaitu analisis sitiran dan paro hidup literatur ( half life) terhadap karya ilmiah dan berbagai penelitian yang telah dihasilkan oleh mahasiswa Instiper. Jurnal Agromast adalah jurnal yang diterbitkan oleh Fakultas Pertanian Instiper yang diterbitkan untuk memuat sebagian skripsi mahasiswa strata satu (S1) Jurusan Agroteknologi dalam format artikel jurnal. Peneliti menggunakan jurnal Agromast untuk analisis sitiran dan paro hidup, karena jurnal ini dapat merepresentasikan penelitianpenelitian mahasiswa Jurusan Agroteknologi. Selain itu, jurnal Agromast menerbitkan artikel-artikel yang cukup konsisten dengan menerbitkan jurnal sebanyak dua kali setiap tahun dari periode 2016 hingga yang termutakhir tahun 2019. Menurut hemat peneliti, jurnal Agromast yang diterbitkan oleh jurusan Agroteknologi lebih aktif menerbitkan jurnal dibandingkan dengan jurusan lainnya. Hal tersebutlah yang menyebabkan peneliti tertarik untuk 
mengetahui dominasi sumber-sumber referensi, jenis referensi, pengarang yang paling banyak disitir, ketersediaan koleksinya di perpustakaan Instiper serta tahun referensi yang digunakan mahasiswa dalam penyusunan karya ilmiah sehingga dari hasil analisis yang dilakukan, data-datanya dapat dipergunakan dalam manajemen pengembangan koleksi khusunya dalam mengevaluasi koleksi perpustakaan. Berdasarkan uraian latar belakang tersebut, penelitian ini memiliki tujuan untuk mengetahui dominasi penggunaan sumber dan jenis referensi yang digunakan mahasiswa serta paro hidup literatur pada jurnal Agromast periode 2018-2019.

Penelitian ini menggunakan data kuantitatif yang pada umumnya dapat dijelaskan melalui angka-angka (Bungin, 2013). Jenis penelitian ini adalah penelitian deskriptif yang berusaha memaparkan pemecahan masalah yang dihadapi saat ini berdasarkan data-data, analisis, dan pemahaman (Narbuko \& Achmad, 2013). Selain menggunakan pendekatan deskriptif kuantitatif penelitian ini juga menggunakan kajian bibliometrika dengan analisis sitiran dan paro hidup litaratur. Analisis sitiran dapat menggambarkan frekuensi pengarang dan jenis koleksi yang sering disitir, sedangkan paro hidup literatur dapat menggambarkan kecenderungan tahun referensi yang disitir dalam penulisan karya ilmiah mahasiswa. Karena keterbatasan waktu, peneliti memfokuskan objek penelitian dengan menggunakan Jurnal Agromast periode tahun 2018-2019 yang diterbitkan oleh Fakultas Pertanian berisikan artikel ilmiah mahasiswa strata satu (S1) jurusan Argoteknologi (Budidaya Pertanian) Fakultas Pertanian Instiper yang dapat diakses melalui situs resmi perpustakaan Instiper yaitu, http://journal.instiperjogja.ac.id/. Jurnal Agromast terbit sebanyak dua kali dalam periode satu tahun di bulan April dan Oktober.

\section{B. HASIL DAN PEMBAHASAN}

\section{Evaluasi Koleksi Perpustakaan}

Evaluasi melengkapi siklus pengembangan pengumpulan dan terkait erat dengan kegiatan penilaian kebutuhan pemustaka. Evaluasi koleksi melibatkan nilai-nilai kuantitatif dan kualitatif. Tujuan utama evaluasi adalah untuk mengetahui seberapa bermanfaat koleksi, kekuatan koleksi, dan seberapa efektif dana yang dihabiskan dalam menyelenggarakan koleksi perpustakaan (Samantaray \& Rath, 2014). Oleh sebab itu, evaluasi menjadi pelengkap dalam siklus pengembangan koleksi dan membawa pada ranah kajian kebutuhan informasi pengguna. Evaluasi koleksi merupakan kegiatan penilaian terhadap bahan perpustakaan dari segi ketersediaan hingga segi kebermanfaatannya bagi pemustaka. Proses terdapat unsur-unsur umum pada definisi terkait dengan penempatan sebuah nilai (value) pada sebuah objek. 
Dari waktu ke watku, dasar-dasar dari evaluasi tidak lah berubah, hanya saja penerapannya yang semakin berkembang.

Bagi perpustakaan kegiatan evaluasi koleksi memiliki beberapa tujuan, di antaranya adalah untuk dapat memahami dengan jelas ruang lingkup, kedalaman, kualitas, kekuatan dan kelemahan koleksi perpustakaan. Selain itu, membantu perpustakaan menentukan efektivitas pengembangan kebijakan koleksi dan menemukan cara untuk meningkatkan kemampuan perpustakaan dalam memenuhi kebutuhan pengguna. Karena efek tersebut, banyak perpustakaan di seluruh dunia telah melakukan evaluasi untuk mengetahui situasi koleksi perpustakaan saat ini sehingga perpustakaan dapat mengetahui apa yang harus mereka lakukan untuk mengembangkan koleksi perpustakaan di masa mendatang. Hasil evaluasi juga mendukung untuk membangun atau menyesuaikan kebijakan pengembangan koleksi perpustakaan, mengukur efektivitas kebijakan pengembangan koleksi, serta menentukan prioritas pelestarian koleksi perpustakaan (Chi, 2016). Poinpoin tersebut dapat dievaluasi melalui beberapa pendekatan umum, seperti menyusun statistik tentang kepemilikan, memeriksa daftar pustaka, memperoleh pendapat dari pengguna biasa, memeriksa koleksi secara langsung, dan mendaftar kapasitas pengiriman dokumen perpustakaan.

Penggunaan data-data dan teknik statistik dapat digunakan dalam melakukan kegiatan evaluasi dengan mengandalkan beberapa indikator kuantitatif yang diterapkan dalam evaluasi koleksi perpustakaan. Asosiasi Perpustakaan Amerika (American Library Association) mengeluarkan pedoman dalam mengevaluasi koleksi atau ALA's Guide to the Evolution of Library Collections yang berdasarkan pada aspek koleksi dan aspek penggunaan. Adapun metode-metode yang fokus pada aspek koleksi adalah dengan mencocokan bibliografi dan katalog; kemudian dengan bantuan pendapat dari pakar disiplin ilmu tertentu; membandingkan data statistik; dan menggunakan standar-standar koleksi. Sedangkan metode yang terpusat pada penggunaan, yaitu: dengan kajian sirkulasi; berdasarkan pendapat pemustaka; data peminjaman antar perpustakaan (inter library loan); kajian analisis sitiran dan penggunaan koleksi di perpustakaan; ketersediaan koleksi; simulasi penggunaan; dan uji penyampaian (Syukrinur, 2017). Analisis sitiran merupakan salah satu metode dalam melakukan kajian pengguna dengan menjadikan dokumen sebagai media analisisnya.

\section{Kajian Bibliometrika}

Istilah bibliometrika diciptakan oleh Alan Pritchyard pada tahun 1969 untuk mempelajari secara kuantitatif tentang pola komunikasi literatur yang diterbitkan dalam suatu bidang ilmu tertentu. Menurut Online Dictionary of Library and Information Science (ODLIS) mendefinisikan bibliometrika 
sebagai penggunaan metode matematika dan statistik untuk mempelajari atau mengidentifikasi pola-pola dalam penggunaan bahan dan layanan di dalam perpustakaan serta menganalisis perkembangan historis dari tubuh literatur tertentu, terutama kepenulisannya, publikasi, dan penggunaan (Singh \& Chander, 2014). Proses mempelajari dan identifikasi ini berguna dalam menjelaskan proses komunikasi, sifat, serta arah perkembangan literatur ilmiah dari segi pengarang, publikasi, hingga penggunaan literatur ilmiah tersebut dalam penelitian-penelitian selanjutnya.

Hasil dari analisis bibliometrika dapat bermanfaat dalam evaluasi layanan-layanan perpustakaan, kebijakan pengembangan koleksi serta kebijakan perbaikan, penyediaan sumber daya dan juga pelaksanaan penyiangan. Kajian ini juga dapat membantu dalam pengambilan keputusan bagi pustakawan dan staf dengan menggunakan data yang telah diperoleh sebagai dasar ilmiah (Pattah, 2013). Bibliometrika telah muncul sebagai alat yang berguna untuk mempelajari evaluasi dan pengembangan koleksi, peringkat jurnal, identifikasi literatur inti, mengetahui struktur literatur, mengetahui penulis profesional, mengamati keusangan literatur, mempelajari perilaku pengguna dan memperkirakan kebutuhan mereka selanjutnya (Singh \& Chander, 2014).

Menurut Sulistyo Basuki, bibliometrika dapat dikelompokkan menjadi dua, yaitu: bibliometrika deskriptif dan evaluatif. Bibliometrika deskriptif dilakukan untuk meninjau produktivitas komunikasi ilmiah berdasarkan aspek geografi, periode waktu, dan disiplin ilmu. Sementara itu, bibliometrika evaluatif digunakan untuk menganalisis perhitungan terhadap penggunaan literatur berdasarkan topik, subjek, atau disiplin ilmu tertentu. Biasanya, objek yang digunakan dalam kajian bibliometrika ialah majalah ilmiah karena dalam penyajiannya memiliki parameter seperti pengarang, judul artikel, judul majalah, tahun terbit, daftar rujukan, sitiran, dan deskriptor yang merupakan ciri-ciri dari majalah ilmiah (Irianti, 2016).

\section{Analisis Sitiran terhadap Jurnal Agromast}

Salah satu komponen utama dalam kajian bibliometrika adalah analisis sitiran, menurut ALA Glossary of Library and Information Science dalam Pattah, (2013), sitiran merupakan catatan atau daftar yang merujuk kepada suatu tulisan yang memuat otoritas atas suatu pernyataan/gagasan yang dikutip dan dituangkan dalam tulisan baru. Daftar referensi dalam penelitian merupakan bagian penting dari karya ilmiah. Dengan merujuk pada daftar referensi yang dapat menghubungkan antara publikasi ilmiah saat ini dengan publikasi sebelumnya, serta menghubungkan ke jaringan publikasi penelitian secara global. Dengan demikan, hal tersebut dapat diasumsikan bahwa kutipan merepresentasikan penggunaan karya yang 
dikutip oleh penulis yang mengutip, dan menunjukkan pengaruh karya yang dikutip pada karya baru penulis tersebut, dan seperti aliran pengetahuan dari penulis kutipan ke penulis karya yang mengutip. Kemudian kutipan juga menunjukkan keterkaitan (misalnya, pokok bahasan serupa atau pendekatan metodologis) antara dua karya yang dikutip dan mengutip (Zhao \& Strotmann, 2015).

Eugene Garfield adalah seorang pelopor dalam bidang analisis sitiran sekaligus pendiri Institute for Scientific Information (ISI) dan menerapkan analisis kutipan dan metrik secara spesifik untuk data bibliografi yang pernah diabaikan dan dipandang hanya sebagai daftar yang ditambahkan ke artikel berkala atau tesis yang diajukan untuk sebuah gelar akademik. Garfield mempertimbangkan pentingnya, memberikan gambaran baru yang ikonik untuk referensi bibliografi sebagai kutipan untuk memperhitungkan nilai-nilai tersembunyi dari daftar biblografi, dan tidak hanya untuk menilai dan mengevaluasi kontributor dokumen saja (Kretschmer et al., 2017).

Secara umum, analisis sitiran dapat secara efektif membantu dalam penemuan pengetahuan baru, pengelolaan, dan penggunaan sumber daya pengetahuan yang ada. Menurut Zhao \& Strotmann (2015), analisis sitasi dapat digunakan untuk:

a. Menilai sumber daya informasi dan mengevaluasi kontribusi ilmiah,

b. Memetakan bidang penelitian untuk mempelajari struktur intelektual,

c. Melacak arus pengetahuan,

d. Mempelajari pengguna dan penggunaan literatur ilmiah, dan

e. Membantu organisasi informasi, perwakilan, dan temu kembali informasi.

Gross \& Gross dalam Pastva et al., (2018) berpendapat bahwa pemeriksaan terhadap literatur menunjukkan preseden yang kuat dari studi analisis sitiran untuk pengembangan koleksi perpustakaan, karena premis umum yang beramsumsi bahwa koleksi yang lebih banyak dikutip lebih berharga untuk koleksi perpustakaan. Sehingga data dari analisis sitiran dapat dijadikan bahan pertimbangan dalam melakukan evaluasi dan pengembangan koleksi.

Jurnal Agromast merupakan jurnal di bidang agroteknologi atau budidaya pertanian, yang diterbitkan oleh Instiper setiap dua kali dalam setahun. Jurnal ini memuat skripsi-skripsi mahasiswa Instiper jurusan Agroteknologi yang telah dirangkum dalam format artikel ilmiah. 
Pada penelitian ini, analisis dilakukan pada tiga volume jurnal yang terbit pada tahun 2018 sampai 2019. Jumlah artikel dalam jurnal Agromast yang dijadikan objek analisis sebanyak 166 artikel yaitu, jurnal Agromast volume 3 No. 2 terbit pada bulan April 2018 memuat 30 judul artikel dengan 519 sitiran, kemudian volume 3 No. 2 terbit pada bulan Oktober 2018 terdapat 130 judul artikel dengan jumlah sitiran sebanyak 2.124. Dan terbitan terbaru pada April 2019 yaitu volume 4 No. 1 yang hanya memuat 6 judul artikel dengan jumlah kutipan sebanyak 137 sitiran. Dari jumlah keseluruhan artikel yang dianalisis, ditemukan sebanyak 2.780 sitiran yang terdapat pada keseluruhan artikel jurnal Agromast. Adapun rekapitulasinya sebagai berikut:

Tabel 1. Jumlah Sitiran dalam Jurnal Agromast

\begin{tabular}{ccccc}
\hline No. & Volume & Tahun & Jumlah Artikel & Jumlah Sitiran \\
\hline 1. & 4 No. 1 & 2019 & 6 Artikel & 137 Sitiran \\
2. & 3 No. 1 & 2018 & 130 Artikel & 2. 124 Sitiran \\
3. & 3 No. 2 & 2018 & 30 Artikel & 519 Sitiran \\
\multicolumn{6}{c}{ Jumlah } & 166 Artikel & 2.780 Sitiran \\
\hline
\end{tabular}

\section{Sumber: Data diolah oleh peneliti}

Jenis sumber rujukan atau bahan informasi yang dijadikan referensi mahasiswa dalam menulis karya ilmiah didominasi oleh jenis rujukan berupa buku-buku sebanyak $74.90 \%$, sumber rujukan buku yang digunakan adalah berupa buku yang diterbitkan oleh berbagai macam perusahaan penerbit swasta, lembaga pemerintahan, pusat penelitian, dan institusi perguruan tinggi. Mahasiswa juga menggunakan sumber rujukan dari artikel ilmiah sebanyak $16.10 \%$, sumber yang digunakan berupa jurnal yang dipublikasikan/tidak dipublikasikan, skripsi, tesis, disertasi, proseding, makalah seminar, dan karya tulis yang bersifat ilmiah lainnya. Kemudian 7\% mahasiswa menggunakan sumber rujukan yang di dapatkan dari website atau situs internet berupa artikel-artikel yang dimuat oleh situs resmi badan pemerintah, pusat penelitian, organisasi, dan perorangan. Selanjutnya, sumber rujukan yang berasal dari data-data, statistik, dan peraturan perundang-undangan yang diterbitkan oleh badan pemerintah, pusat statistik, pusat penelitian, dan organisasi, digunakan mahasiswa sebanyak $2 \%$. Seperti yang dimuat dalam tabel 2 . berikut:

Tabel 2. Jenis Sumber Rujukan yang digunakan

\begin{tabular}{|c|c|c|c|}
\hline No & Jenis Sumber Rujukan & Jumlah & Persentase (\%) \\
\hline 1. & Buku & 1.930 & $74.90 \%$ \\
\hline 2. & Karya Ilmiah & 417 & $16.10 \%$ \\
\hline 3. & Sumber & 178 & $7 \%$ \\
\hline
\end{tabular}




\begin{tabular}{lcc}
\hline Website/Situs Internet & & \\
4. $\begin{array}{l}\text { Data, Statistik, Peraturan } \\
\text { Perundang-Undangan, } \\
\text { dll. }\end{array}$ & 54 & \\
& & \\
\hline
\end{tabular}

Sumber: Data diolah oleh peneliti

\section{Dominasi Pengarang yang Disitir}

Berdasarkan hasil analisis sitiran terhadap 166 artikel, peneliti memberikan acuan pada pengarang yang dikategorikan sebagai pengarang yang paling banyak disitir adalah pengarang yang dikutip lebih dari 20 kali dalam keseluruhan artikel jurnal. Jika diurutkan, peringkat pertama yang paling banyak dikutip dalam penulisan karya ilmiah mahasiswa jurusan Agroteknologi adalah Iyung Pahan sebanyak 105 sitiran. Pada peringkat kedua terbanyak Adlin U. Lubis dengan jumlah 60 sitiran, dan peringkat ketiga adalah Rachman Sutanto sebanyak 46 sitiran. Kemudian peringkat keempat, Maruli Pardamean sebanyak 39 sitiran, selanjutnya Rustam Effendi Lubis dan A. Widanarko (37 sitiran), Darmawijaya (34 sitiran), Suyatno Risza (29 sitiran), Direktorat Jenderal Perkebunan (25 sitiran), Sunarko (24 sitiran), Mangoensoekarjo \& Semangun (21 sitiran), dan Mangoensoekarjo \& A. T. Tojib (20 sitiran). Berikut ini adalah rekapitulasi pengarang yang dikutip lebih dari 20 kali dari keseluruhan artikel jurnal:

Tabel 3. Penulis yang Paling Banyak Disitir

\begin{tabular}{|c|c|c|c|c|c|}
\hline Peringkat & Nama Pengarang & $\begin{array}{c}\text { Vol. 4, } \\
\text { No.1 } \\
\text { Apr-19 }\end{array}$ & $\begin{array}{c}\text { Vol. 3, } \\
\text { No. } 1 \\
\text { Apr-18 }\end{array}$ & $\begin{array}{c}\text { Vol. } 3 \text {, } \\
\text { No. } 2 \\
\text { Okt-18 }\end{array}$ & Jumlah \\
\hline 1. & Iyung Pahan & 7 & 83 & 15 & 105 \\
\hline 2. & Adlin U. Lubis & 3 & 38 & 19 & 60 \\
\hline 3. & Rachman Sutanto & 2 & 39 & 5 & 46 \\
\hline 4. & Maruli Pardamean & 3 & 33 & 3 & 39 \\
\hline 5. & $\begin{array}{l}\text { Rustam Efendi Lubis dan } \\
\text { A. Widanarko }\end{array}$ & 4 & 29 & 4 & 37 \\
\hline 6. & Darmawijaya & 4 & 25 & 5 & 34 \\
\hline 7. & Suyatno Risza & 4 & 20 & 5 & 29 \\
\hline 8. & $\begin{array}{l}\text { Direktorat } \\
\text { Perkebunan }\end{array}$ & 6 & 17 & 2 & 25 \\
\hline 9. & Sunarko & 4 & 16 & 4 & 24 \\
\hline 10. & $\begin{array}{l}\text { Mangoensoekarjo } \quad \& \\
\text { Semangun }\end{array}$ & 4 & 17 & 0 & 21 \\
\hline 11. & $\begin{array}{l}\text { Mangoensoekarjo \& A. T. } \\
\text { Tojib }\end{array}$ & 0 & 19 & 1 & 20 \\
\hline
\end{tabular}


Sumber: data diolah oleh peneliti

\section{Ketersediaan Koleksi di Perpustakaan}

Sebagian besar pengarang yang paling banyak dikutip merupakan penulis dan peneliti di bidang perkebunan dan kelapa sawit. Beberapa koleksi dari pengarang-pengarang yang paling banyak disitir tersebut dapat ditemukan di perpustakaan Instiper. Berdasarkan hasil analisis, dapat diketahui bahwa ada sebanyak 2.780 sitiran dari 2.579 jenis referensi yang digunakan. Dari keseluruhan sitiran, 2.110 sitiran yang dapat teridentifikasi melalui pencaharian katalog perpustakaan Instiper, hal ini dikarenakan 670 sitiran yang bersumber dari situs internet dalam bentuk karya ilmiah elektronik/jurnal elektronik, data statistik, modul, peraturan perundangundangan, dan artikel dalam situs website sehingga tidak dapat ditemukan di perpustakaan.

Ada sebanyak 1.144 sitiran (54\%) yang referensi atau buku terdapat di perpustakaan Instiper berupa buku-buku dari penulis yang sering dikutip. Berikut ini adalah rekapitulasi ketersediaan koleksi di perpustakaan berdasarkan peringkat yang paling banyak disitir dalam penulisan artikel ilmiah jurnal Agromast periode tahun 2018-2019:

Tabel 4. Ketersediaan Koleksi

\begin{tabular}{|c|c|c|c|}
\hline Peringkat & Judul Buku & Pengarang & $\begin{array}{l}\text { Jumlah } \\
\text { Sitiran }\end{array}$ \\
\hline 1 & $\begin{array}{l}\text { Panduan Lengkap Kelapa Sawit: } \\
\text { Manajemen Agribisnis dari Hulu Hingga } \\
\text { Hilir }\end{array}$ & Iyung Pahan & 77 Sitiran \\
\hline 2 & $\begin{array}{l}\text { Kelapa Sawit (Elaeis Guineensis Jacq) di } \\
\text { Indonesia }\end{array}$ & Andlin U. Lubis & 34 Sitiran \\
\hline 3 & Buku Pintar Kelapa Sawit & $\begin{array}{l}\text { Rustam Efendi Lubis \& } \\
\text { A. Widanarko }\end{array}$ & 31 Sitiran \\
\hline 4 & $\begin{array}{l}\text { Sukses Membuka Kebun dan Pabrik } \\
\text { Kelapa Sawit }\end{array}$ & Maruli Pardamean & 22 Sitiran \\
\hline 5 & $\begin{array}{l}\text { Penerapan Pertanian Organik: } \\
\text { Pemasyarakatan dan Pengembangannya }\end{array}$ & Rachman Sutanto & 17 Sitiran \\
\hline 6 & $\begin{array}{l}\text { Pertanian Organik: Menuju Pertanian } \\
\text { Alternatif dan Berkelanjutan }\end{array}$ & Rachman Sutanto & 11 Sitiran \\
\hline 7 & Kupas Tuntas Agribisnis Kelapa Sawit & Maruli Pardamean & 8 Sitiran \\
\hline 8 & $\begin{array}{l}\text { Mengelola Kebun dan Pabrik Kelapa } \\
\text { Sawit Secara Profesional }\end{array}$ & Maruli Pardamean & 5 Sitiran \\
\hline
\end{tabular}




\begin{tabular}{clll}
\hline $\mathbf{9}$ & $\begin{array}{l}\text { Panduan Lengkap Pengelolaan Kebun } \\
\text { dan Pabrik Kelapa Sawit }\end{array}$ & Maruli Pardamean & 4 Sitiran \\
$\mathbf{1 0}$ & $\begin{array}{l}\text { Dasar-Dasar Ilmu Tanah: Konsep dan } \\
\text { Kenyataan }\end{array}$ & Rachman Sutanto & 3 Sitiran \\
\end{tabular}

\section{Sumber: data diolah oleh peneliti}

Selanjutnya sebanyak 966 sitiran (46\%) yang referensinya tidak terdapat di perpustakaan, jenis-jenis koleksi yang tidak ditemukan di katalog perpustakaan Instiper sebagian besar adalah referensi yang diterbitkan oleh institusi pendidikan dan lembaga-lembaga tertentu. Selaras dengan data tersebut, dapat ditarik kesimpulan bahwa sebagaian besar mahasiswa dapat menemukan dan menggunakan koleksi perpustakaan dalam proses penulisan tugas akhir mahasiswa jurusan Agroteknologi Instiper.

\section{Paro Hidup Litertaur (Half-Life) Terhadap Jurnal Agromast}

R. E. Borton dan R. W. Kebler merupakan yang pertama kali memperkenalkan istilah paro hidup (half-life) pada tahun 1960, mereka menggunakan istilah "half-life" yang berarti saat separuh waktu dari seluruh literatur suatu disiplin ilmu yang digunakan secara terus menerus. Line menyatakan bahwa paro hidup literatur adalah batas kecepatan atau tidaknya pertumbuhan suatu dokumen atau literatur (Venny, 2013). Menurut Diodato dalam Hartinah (2014), paro hidup merupakan metode dalam mengidentifikasi kekayaan dan kemiskinan informasi yang digunakan oleh penulis dalam kepenulisan ilmiah. Rentang waktu yang dibutuhkan oleh separuh literatur yang dikutip oleh literatur terakhir yang diterbitkan dalam bidang ilmu tertentu disebut dengan paro hidup sitiran.

Paro hidup merupakan rentang waktu literatur digunakan sebanyak $50 \%$ atau separuh penggunaan dari total keseluruhan literatur tersebut. Dengan cara mengurangi median tahun terbit dokumen yang menyitir dengan tahun terbit dokumen yang disitir dapat mengetahui paro hidup literatur suatu disiplin bidang ilmu (Venny, 2013). Dalam kajian bibliometrika, analisis paro hidup terhadap literatur dapat menunjukkan tingkat keusangan literatur suatu disiplin ilmu tertentu berdasarkan analisis sitiran, kemutakhiran sumber informasi yang terkandung dalam literatur dapat ditunjukkan melalui keseluruhan tahun terbit sitiran pada suatu literatur tersebut. Untuk dapat mengetahui nilai median pada tahun terbit referensi perlu menggunakan rumus-rumus berikut (Kartika, et.al., 2016):

a) Menentukan kelompok kelas dengan rumus:

$$
K=1+3,322 \log n
$$

$(\mathrm{n}=$ jumlah sitiran dalam literatur) untuk penentuan kelas atau kelompok data. 
190 | TIK ILMEU: Jurnal IImu Perpustakaan dan Informasi, vol. 4, no. 2, 2020

b) Menghitung tahun terbit tertinggi dan terendah menggunakan rumus range:

$$
\mathbf{R}=\mathbf{X}_{\mathbf{n}}(\text { Tahun termuda })-\mathbf{X}_{1}(\text { Tahun Tertua })
$$

c) Menentukan Interval menggunakan rumus:

$$
\boldsymbol{I}=\frac{\boldsymbol{R}}{\boldsymbol{K}}
$$

$R$ : jarak antara tahun terbit tertinggi dengan tahun terbit terendah.

$K$ : banyaknya kelompok tahun terbit.

d) Membuat tabel distribusi frekuensi kumulatif

e) Menentukan usia paro hidup dengan rumus:

$$
\boldsymbol{X n}-\boldsymbol{M d} \text {. }
$$

Dan median, yaitu: $\quad \boldsymbol{M d}=\boldsymbol{L} \boldsymbol{m \boldsymbol { d }}+\frac{(\boldsymbol{J} \boldsymbol{m} \boldsymbol{d})}{(\boldsymbol{F m d})}+\boldsymbol{i}$

$X n=$ Tahun Termuda

Md = Median

Lmd = Kelas nyata bawah pada saat frekuensi kumulatif mangandung $\mathrm{n} / 2$

Jmd $=$ Selisih $\mathrm{n} / 2$ dengan frekuensi kumulatif mengandung $\mathrm{n} / 2$

Fmd $=$ Frekuensi pada saat frekuensi kumulatif mengandung n/2

$\mathrm{I}=$ interval.

Analisis paro hidup menekankan pada tahun terbit sitiran secara keseluruhan dalam suatu dokumen, tahun terbit sitiran menunjukkan tingkat kemutakhiran informasi yang terkandung dalam literatur ilmiah. Hasil dari analisis paro hidup dapat dijadikan parameter tentang kekayaan dan kemiskinan informasi yang terkandung dalam bahan perpustakan. Semakin baru suatu literatur diterbitkan, maka semakin sering literatur tersebut dikutip oleh karya tulis lainnya. Pada perpustakaan perguruan tinggi, kajian paro hidup literatur dapat dijadikan sebagai bahan pertimbangan dan pengambilan keputusan dalam pengadaan koleksi yang sesuai dengan kebutuhan pemustaka.

Untuk mengetahui paro hidup literatur, dapat dilakukan beberapa tahap yaitu: menentukan kelompok kelas dengan rumus: 


$$
\begin{aligned}
& K=1+3.322 \times \log n \\
& K=1+3.322 \times \log 2596 \\
& K=1+11.34 \\
& K=12.34 \\
& K=12
\end{aligned}
$$

Menentukan tahun terbit tertinggi dan terendah menggunakan rumus range:

$$
\begin{aligned}
& \mathrm{R}=\mathrm{X}_{\mathrm{n}}(\text { Tahun termuda })-\mathrm{X}_{1}(\text { Tahun Tertua) } \\
& R=2019-1949 \\
& R=70
\end{aligned}
$$

Menghitung Interval menggunakan rumus:

$$
\begin{aligned}
& I=\frac{R}{K} \\
& I=\frac{70}{12} \\
& I=5.83=6
\end{aligned}
$$

Membuat tabel distribusi frekuensi kumulatif

\section{Tabel 5. Distribusi Frekuensi Tahun Terbit Sitiran}

\begin{tabular}{cccc}
\hline No. & $\begin{array}{c}\text { Periode Tahun } \\
\text { Sitiran }\end{array}$ & $\begin{array}{c}\text { Jumlah } \\
\text { Sitiran }\end{array}$ & $\begin{array}{c}\text { Frekuensi } \\
\text { Kumulatif }\end{array}$ \\
\hline 1. & $1945-1950$ & 6 & 6 \\
2. & $1951-1955$ & 4 & 10 \\
3. & $1956-1960$ & 4 & 14 \\
4. & $1961-1965$ & 6 & 20 \\
5. & $1966-1970$ & 12 & 32 \\
6. & $1971-1975$ & 31 & 63 \\
7. & $1976-1980$ & 36 & 99 \\
8. & $1981-1985$ & 87 & 186 \\
9. & $1986-1990$ & 148 & 334 \\
10. & $1991-1995$ & 318 & 652 \\
11. & $1996-2000$ & 164 & 816 \\
12. & $2001-2005$ & 441 & 1257 \\
13. & $2006-2010$ & 608 & 1865 \\
14. & $2011-2015$ & 603 & 2468 \\
15. & $2016-2020$ & 128 & 2596 \\
& Jumlah & $\mathbf{2 5 9 6}$ & \\
\hline
\end{tabular}


Menghitung usia paro hidup dengan rumus: $\frac{n}{2}=\frac{2596}{2}=1298$ maka kelas nyata bawah frekuensi kumulatif yang mengandung $\frac{n}{2}$ (Lmd) terletak pada tahun 2006, maka kelas nyata bawahnya adalah $2016-0.5=2005.5$ jadi, Lmd $=2005,5$. Frekuensi kumulatif mengandung $\frac{n}{2}$ jatuh pada jumlah sitiran dalam rentang waktu antara tahun $2006-2010$ maka, Fmd $=608$. Selanjutnya, frekuensi kumulatif mengandung $\frac{n}{2}$ terdapat pada frekuensi sitiran 1865 maka, Jmd adalah $1865-1298=567$. Dan menghitung median, yaitu:

$$
\begin{aligned}
M d & =L m d+\frac{(J m d)}{(F m d)}+i \\
M d & =2005.5+\frac{567}{608} \times 6 \\
M d & =2005.5 \times 5.60 \\
M d & =2011.1
\end{aligned}
$$

Selanjutnya, untuk menghitung usia paro hidup Jurnal Argomast menggunakan rumus:

$$
\begin{aligned}
\text { Paro Hidup } & =X n-M d . \\
& =2019-2011.1 \\
& =7.9=8 \text { Tahun }
\end{aligned}
$$

Berdasarkan uraian perhitungan di atas, dapat diketahui bahwa usia paro hidup literatur yang dikutip pada jurnal Agromast secara keseluruhan dari tahun 2018 sampai 2019 adalah 8 tahun. Hal ini menunjukkan literatur yang disitir dari tahun terbit 1949 sampai 2010 dianggap telah usang, sedangkan literatur yang disitir dari tahun 2011 sampai 2019 dianggap menggunakan literatur atau rujukan yang mutakhir. Berdasarkan tabel 5. distribusi frekuensi tahun terbit sitiran, literatur yang dianggap usang sebanyak 1.865 sitiran dengan persentase $75.59 \%$. Sedangkan literatur yang dianggap mutakhir sebanyak 731 sitiran dengan persentase 28.15\%. Dari perhitungan tersebut, dapat disimpulkan bahwa usia literatur yang disitir dalam penulisan artikel jurnal Agromast cenderung menggunakan literatur yang dianggap usang atau tidak mutakhir. Perihal tersebut perlu diperhatikan oleh perpustakaan Instiper dalam menyediakan sumber-sumber informasi yang mutakhir bagi pemustaka. Hasil dari kajian ini dapat digunakan oleh pustakawan dalam melakukan pengadaan koleksi yang mutakhir untuk kebutuhan pemustaka. 


\section{KESIMPULAN}

Berdasarkan hasil analisis pada jurnal Agromast dan pembahasan yang telah dipaparkan di atas, dapat disimpulkan bahwa jenis referensi buku dan artikel ilmiah menjadi sumber rujukan yang paling dominan digunakan oleh mahasiswa dalam penulisan tugas akhir yang dimuat dalam jurnal Agromast. Kemudian, usia paro hidup literatur yang dikutip pada jurnal Agromast secara keseluruhan adalah 8 tahun. Ada sebanyak $75.59 \%$ literatur yang dianggap usang karena lebih dari separuh waktu dari penggunaan total literatur, yaitu literatur yang disitir dari tahun terbit 1949 sampai 2010, sedangkan literatur yang dianggap mutkhir sebanyak $28.15 \%$, yaitu literatur yang disitir dari tahun 2011 sampai 2019. Hal ini menunjukkan bahwa literatur yang digunakan dalam penulisan jurnal Agromast pada periode tahun 2018-2019 cenderung menggunakan literatur yang dianggap usang atau tidak mutakhir.

Perpustakaan Instiper Yogyakarta perlu melakukan evaluasi secara berkala untuk mengetahui kebutuhan sumber informasi pemustaka atau mahasiswa, kajian bibliometrika dapat diterapkan oleh pustakwan sebagai bahan masukan saat melakukan evalusai dan pengembangan koleksi. Perpustakaan juga perlu melakukan pengembangan koleksi dengan tahun terbit yang termutakhir atau menambah koleksi yang tahun terbitnya dalam rentang 8 tahun terakhir, sehingga perpustakaan memiliki sumber informasi dan koleksi yang up to date untuk dapat dimanfaatkan oleh pemustaka.

\section{DAFTAR RUJUKAN}

Bungin, Burhan (2013). Metodologi Penelitian Kuantitatif: Komunikasi, Ekonomi, dan Kebijakan Publik serta Ilmu-Ilmu Sosial Lainnya. Jakarta: Kencana.

Chi, T. P. D. (2016). Collection evaluation i libraries. International Journal of Development Research.

Fatchiyah (2016). Strategi Penulisan Artikel Ilmiah. Malang: Universitas Brawijaya Press.

Hartinah, Sri (2014). Metode Penelitian Perpustakaan. Tangerang Selatan: Universitas Terbuka.

Irianti, P. (2016). Studi Bibliometri Media Komunikasi Ilmiah Berkala Ilmu Perpustakaan dan Informasi. JURNAL IPTEKKOM: Jurnal Ilmu Pengetahuan \& Teknologi Informasi. https://doi.org/10.33164/iptekkom.18.1.2016.69-80

Kretschmer, H., Kretschmer, T., A Y, A., \& Ravichandra Rao, I. K. (2017). Dr. Eugene Garfield A humble Homage to a great information scientist. 
194 | TIK ILMEU: Jurnal IImu Perpustakaan dan Informasi, vol. 4, no. 2, 2020

COLLNET Journal of Scientometrics and Information Management. https://doi.org/10.1080/09737766.2017.1344001

Muchlisin, Z. A. (2018). Kiat Menulis Artikel Ilmiah Jurnal Nasional dan Internasional. Banda Aceh: Syiah Kuala University Press.

Narbuko, Cholid dan Achmad, Abu (2013). Metodologi Penelitian. Jakarta: Bumi Aksara.

Pastva, J., Shank, J., Gutzman, K. E., Kaul, M., \& Kubilius, R. K. (2018). Capturing and analyzing publication, citation, and usage data for contextual collection development. Serials Librarian. https://doi.org/10.1080/0361526X.2018.1427996

Pattah, S. H. (2013). Pemanfaatan Kajian Bibliometrika sebagai Metode Evaluasi dan Kajian dalam Ilmu Perpustakaan dan Iinformasi. In Jurnal Ilmu Perpustakaan \& Informasi KHIZANAH AL-HIKMAH.

Kartika, Putu Gede Krisna Yudhi, dkk. (2016). Usia Paro Hidup dan Keusangan Literatur Jurnal Skala Husada. Jurnal Ilmiah D3 Perpustakaan Universitas Udayana

https://ojs.unud.ac.id. Pada tanggal 27 Oktober 2019.

Samantaray, Moorttimatee dan Rath, Pravakar (2014). Collection Development in Libraries: Challenges and Solutions For Library Professionals. A Journal of Library and Information Science.

https://www.researchgate.net/publication/271353061_Collection_Devel opment_in_Libraries_

Challenges_and_Solutions_for_Library_Professionals. Pada tanggal 11 Mei 2020.

Singh, K. P., \& Chander, H. (2014). Publication trends in library and information science: A bibliometric analysis of Library Management journal. Library Management. https://doi.org/10.1108/LM-05-20130039

Syukrinur. (2017). Evaluasi Koleksi : Antara Ketersediaan dan Keterpakaian Koleksi. LIBRIA.

Venny Vania Annora Manullang (2013). Analisis Paro Hidup Literatur pada Jurnal Information Research Periode 2008-2011.

http://journal.unair.ac.id

Zhao, D., \& Strotmann, A. (2015). Analysis and Visualization of Citation Networks. Synthesis Lectures on Information Concepts, Retrieval, and Services. https://doi.org/10.2200/s00624ed1v01y201501icr039 